\title{
Kinect Adventures versus physical exercise on depressive symptoms of older adults: A pilot study
}

\author{
Kinect Adventures versus exercício físico sobre sintomas \\ depressivos em idosos: Um estudo piloto
}

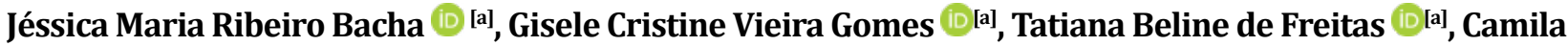

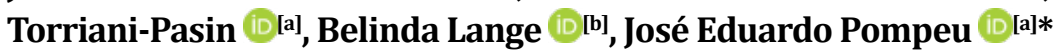

[a] Universidade de São Paulo (USP), São Paulo, SP, Brazil

${ }^{[b]}$ Flinders University, Adelaide, Australia

\begin{abstract}
Introduction: Depressive and anxiety disorders are considered the main cause of emotional suffering and decrease of quality of life among older adults. It has been suggested that the practice of physical exercise can be a treatment option for anxiety and depression. Alternative approaches such serious games show promise for reducing depression symptoms. Objective: To compare the effect of virtual reality, in the form of commercially available interactive Kinect Adventures video games, compared to a standard physical exercise program on depressive symptoms of older adults. Method: This is a pilot study, parallel group, single-blind randomized controlled pilot trial that recruited two intervention groups: Interactive Video Game Kinect Adventures (IVG, n=8) versus usual physical exercise program (PEP, n=6). The two groups completed a seven week program with a total of fourteen 60 -minute sessions divided into two sessions a week. The IVG completed individual training sessions using the Microsoft Xbox Kinect Adventures games and the PEP performed a group exercise program. Depression symptoms were measured using the Geriatric
\end{abstract}

*JMRB: Doctoral student, e-mail: jessicarbacha@hotmail.com

GCVG: Doctoral student, e-mail: gigicv.gomes@gmail.com

TBF: MS, e-mail: tatibeline@gmail.com

CTP: PhD, e-mail: camipasin@usp.br

BL: PhD, e-mail: belinda.lange@flinders.edu.au

JEP: PhD, e-mail: j.e.pompeu@usp.br 
Depression Scale (GDS-15). This measure was assessed pre-intervention, post intervention and at 30-day follow-up. Results: There was a significant effect of assessment without group effect or interaction between factors, in the GDS-15 (RM-ANOVA, P < 0.0001). Both groups showed improvement in the GDS-15 post intervention assessment that was maintained after 30-day follow-up (Bonferroni post hoc test, $\mathrm{P}<0.05$ ). Conclusion: The results of this study suggest that both Interactive Kinect Adventures video games and physical exercise provide beneficial effects on depressive symptoms of older adults.

Keywords: Aged. Mood Disorders. Depression. Exercise. Virtual Reality.

\section{Resumo}

Introdução: Os transtornos depressivos e de ansiedade são considerados a principal causa de sofrimento emocional e diminuição da qualidade de vida de idosos. Foi sugerido que a prática de exercício físico pode ser um tratamento para depressão. Abordagens alternativas, como jogos interativos, podem reduzir sintomas depressivos. Objetivo: Comparar o efeito da realidade virtual, na forma de videogames interativos Kinect Adventures disponíveis comercialmente, em comparação com um programa de exercícios físicos padrão sobre sintomas depressivos de idosos. Método: Trata-se de um estudo piloto, grupos paralelos, experimental, controlado, randomizado, cego através de dois grupos de intervenção: Interactive Video Game Kinect Adventures $(I V G, n=8)$ versus programa de exercício físico (PEF, $n=6)$. Os dois grupos completaram um programa de sete semanas com um total de 14 sessões de 60 minutos divididas em duas sessões por semana. O IVG concluiu sessões de treinamento individuais usando os jogos Microsoft Xbox Kinect Adventures e o PEF realizou um programa de exercícios em grupo. Os sintomas de depressão foram mensurados através da Escala de Depressão Geriátrica (GDS-15). Essas medidas foram avaliadas pré-intervenção, pós-intervenção e no seguimento de 30 dias. Resultados: Houve um efeito significativo da avaliação sem efeito grupo ou interação entre fatores, no GDS-15 (RM-ANOVA, $P<0,0001$ ). Ambos os grupos apresentaram melhora na avaliação pós-intervenção GDS15, que foi mantida após 30 dias de acompanhamento (teste post hoc de Bonferroni, $P<0,05$ ). Conclusão: Os resultados deste estudo sugerem que os jogos interativos Kinect Adventures e o exercício físico proporcionam efeitos positivos nos sintomas depressivos de idosos.

Palavras-chave: Idoso. Transtorno de Humor. Depressão. Exercício. Realidade Virtual.

\section{Introduction}

Depressive and anxiety disorders are considered the main cause of emotional suffering and decrease of quality of life among older adults. These symptoms occur frequently and it is a public health problem of great magnitude, due to its elevated morbidity and mortality [1]. The prevalence of depression in the older adults varies between $5 \%$ and $35 \%$, considering the different forms and severity of the disease. About $15 \%$ to $20 \%$ of older adults, who have other clinical problems, have depressive symptoms, which can vary according to gender, education, socioeconomic status, health conditions, presence of cognitive and precarious social situation [2]. As depressive illness is multifactorial, it can contribute to greater vulnerability to other morbidities, which compromises the functional capacity of the older adults [3].

Depression can be treated through tricyclic antidepressants, psychopharmacological and hormonal drugs, light therapy, electroconvulsive therapy [4], meditation and cognitive behavioral therapy. It has been suggested that the practice of physical exercise can be a treatment option for anxiety and depression [5].

Studies have shown that adherence to a regular program of physical exercises can significantly improve the cognitive performance and reduce depressive symptoms in older adults [6 - 8]. Beneficial effects of physical activity on depressive symptoms are: (1) exercise-induced increase in blood circulation to the 
brain and by an influence on the hypothalamic-pituitaryadrenal axis and, thus, on the physiologic reactivity to stress [9]; (2) exercises include distraction, self-efficacy, and social interaction [10]; (3) exercise improved mental health by reducing anxiety, depression and negative mood and by improving alleviate self-esteem and social withdrawal and $(4,5)$ health benefits from regular exercise that should be emphasized and reinforced in the literature included the following: stimulates the release of neurotransmitters responsible for wellbeing, which often changes in depression; improve sleep; better endurance, stress relief, increase energy and stamina. All of these benefits tend to decrease depressive symptoms in humans [9 - 11].

Alternative approaches such as digital interventions (including online or computerized programs or applications) and serious games show promise for reducing depression and anxiety symptoms [12]. The use of virtual reality (VR) has aroused the interest of health professionals and researchers, as it allows users to face situations through standardized environments that emulate reality. VR environment is capable of evoking emotional states such as anxiety and to change behaviors very similar to those experienced in everyday life [13]. In the past 15 years VR has been used for physical rehabilitation (e.g., stroke, Parkinson's disease, and developmental disabilities) and psychological rehabilitation (e.g., phobias, post-traumatic stress disorder, and autism) [14 - 16]. However, currently, this intervention has been also showing positive effects in the treatment of different health conditions, such as phobias, obesity, chronic pain, anxiety and depression [17].

Technology through VR offers new opportunities for developing scenarios that would be very difficult, or even impossible, to achieve using conventional methods. In relation to its intervention in patients with a predisposition to develop depression, the development of a methodology to work in virtual environments may allow the development of very ecological rehabilitation techniques and strategies [18]. Thus, the objective of this study was to compare the effects of using virtual reality through commercial Interactive Video Game Kinect Adventures with physical exercises program in the depressive symptoms of older adults.

\section{Hypotheses}

Our hypotheses were that an intervention with Interactive Video Game Kinect Adventures would have a significantly great effect on reducing depressive symptoms than a usual physical exercise program. According to the reasons: the games offer higher visual and auditory feedback, the score system related to the performance can increase the engagement and motivation of the participants and the cognitive demands.

\section{Method}

Trial design

This was a parallel group, single-blind randomized controlled pilot trial (using Kinect Adventures) versus a commonly used physical exercise program. The study was developed based on the Consolidated Standards of Reporting Trials (CONSORT) statement.

\section{Ethical approval and consent to participate}

This study was approved by the Ethics Committee of the Medical School of the University of Sao Paulo, Brazil (1.184.941) (Certificate of Presentation for Ethical Appreciation [CAAE]: 45547415.8.0000.0065) and registered in the Brazilian Registry of Clinical Trials (RBR-4z4f48) in November/2015.

Study setting

All participants were recruited from the multidisciplinary care group for the outpatient elderly (GAMIA), located in a tertiary hospital of the medical school, University of São Paulo, Brazil.

Eligibility criteria

\section{Inclusion criteria}

Eligible participants were community dwelling older adults, aged between 60 and 80 years, both genders, capable of walking without assistance, with normal or corrected visual and auditory acuity, without any clinical changes that could preclude the performance of physical exercises in an orthostatic position, such as cardiovascular, orthopedic, or neurological conditions, capable of understanding and interacting with the Kinect games, but without previous experience with them, and who agreed to provide written informed consent. 
Exclusion criteria

The exclusion criteria were as follows: older adults who scored zero in the familiarization session were excluded.

\section{Assessments}

One trained researcher, blinded to treatment allocation, evaluated all participants at three time points: pre, post and 30-days after the end of the intervention (follow-up). Participants were asked to not give any information to the evaluator regarding the intervention they received.

\section{Intervention}

The protocols of this arm of the randomized clinical trial have been published previously by Bacha et al. [19]. The two groups performed fourteen 60-minute sessions twice a week. In order to avoid fatigue during the training sessions, two minute bouts of activity were separated by two minutes of rest.

\section{Interactive Video Game Kinect Adventures Group}

The Interactive Video Game Kinect Adventures group (IVG) performed individual sessions through Microsoft Xbox360 Kinect Adventures games. Participants were provided with an opportunity to learn about and interact with the games through a familiarization practice session. In this session the therapist presented the equipment and explained the rules of each game. Subsequently, participants practiced two attempts at each game, performed with the aid of the therapist to correct the movements and posture of individuals through manual guidance and give feedback through verbal commands, instructing them on the best and most correct way to perform the movement to achieve the goal of the game.

In each training session, the participants played four games (Space Pop, 20,000 Leaks, Reflex Ridge and River Rush) and were allowed five attempts at each game, without interference from the physical therapist. Before the games, the physiotherapist reminded the participant of the correct execution of the movements present in the games, such as: angle for squatting, jumping, elevation of upper limbs, abdominal contraction and emphasizing the importance of maintaining the breathing cycle during games. However, during the execution of the protocol there was no interference in the results. Participants played the games in front of a 50" TV at a distance of three meters from the Microsoft Xbox 360 video game console and Kinect sensor. The description of the four selected games has been outlined in a previously published paper [19] (Table 1).

Table 1 - Description from interactive video game Kinect Adventures

\begin{tabular}{ll}
\hline Games & \multicolumn{1}{c}{ Description } \\
\hline "20,000 Leaks" & $\begin{array}{l}\text { Game the avatar of the player is inside a } \\
\text { glass cube on the seabed and fish and } \\
\text { sharks begin to stick to the glass, which } \\
\text { causes water to enter the cube. The } \\
\text { player's goal is to plug the holes with their } \\
\text { hands and feet, which requires rapid limb } \\
\text { movements. }\end{array}$ \\
\hline "Space pop" & $\begin{array}{l}\text { Game several bubbles appear on the } \\
\text { screen and the player must fly by flapping } \\
\text { their arms like a bird to pop the bubbles. }\end{array}$ \\
\hline "Reflex ridge" & $\begin{array}{l}\text { Game the player moves around on a } \\
\text { platform on a track and must avoid } \\
\text { obstacles by rapidly shifting sideways or } \\
\text { bending down. }\end{array}$ \\
\hline "River rush" & $\begin{array}{l}\text { Game the avatar of the player is in a boat } \\
\text { and must move downstream. To move the } \\
\text { boat, the player needs to move their body } \\
\text { to each side. }\end{array}$ \\
\hline
\end{tabular}

\section{Physical Exercise Program (PEP)}

The intervention of PEP was supervised by a physical therapist and the participants were divided into groups of six. Every physical therapist who supervised this group received prior training, in which all exercises were passed on so that there was no discrepancy and bias in the execution of the proposed protocol. The PEP protocol included seven types of exercises: warmup; static and dynamic balance; (3) endurance; muscle strength; motor coordination; muscle stretching exercises and cool down. The extended description of this training is outlined in Bacha et al. [19] (Table 2). 
Table 2 - Description from Physical Exercise Program

\begin{tabular}{ll}
\hline Exercises & \multicolumn{1}{c}{ Description } \\
\hline Warm-up & Was performed by walking. \\
\hline Static and dynamic & $\begin{array}{l}\text { Static balance training was performed } \\
\text { by means of exercise on the balance } \\
\text { disc and circular balance board. } \\
\text { Dannamic balance training through } \\
\text { two circuits: with unstable ground } \\
\text { associated with upper and lower limb } \\
\text { movements. }\end{array}$ \\
\hline Endurance & $\begin{array}{l}\text { Were performed by raising and } \\
\text { lowering the front and lateral steps and } \\
\text { performing plantar flexion. A shoulder } \\
\text { adduction exercise was also performed } \\
\text { by tightening a ball with the hands and } \\
\text { hip adduction, tightening a ball between } \\
\text { the knees. }\end{array}$ \\
\hline Muscle stretching & $\begin{array}{l}\text { Were performed by raising and } \\
\text { lowering the front and lateral steps and } \\
\text { performing plantar flexion. A shoulder } \\
\text { adduction exercise was also performed } \\
\text { by tightening a ball with the hands and } \\
\text { hip adduction, tightening a ball between } \\
\text { the knees. }\end{array}$ \\
\hline Muscle strength & $\begin{array}{l}\text { Consisted of global stretches. } \\
\text { Consisted of a circuit where the patient } \\
\text { had to move on their back. }\end{array}$ \\
\hline and joint mobilizations of the cervical, \\
upper, and lower limbs.
\end{tabular}

\section{Outcome measures}

Socio-demographic and clinics data were collected from individuals to characterize the sample, such as: age, weight, height, body mass index, gender, number of diseases, number of medications in use and physical activity level. This last was measured through the International Physical Activity Questionnaire (IPAQ) [20].

The study outcome was the number of depressive symptoms, measured through the Geriatric Depression Scale (GDS-15) [21]. The GDS is one of the instruments used in the screening of depression symptoms in older adults.

\section{Sample size}

For a pilot study, a sample calculation was not performed; a small sample of 14 participants was recruited.
Recruitment

Potentially eligible participants were invited to participate in the study through advertising in the local community of the city of Sao Paulo, Brazil.

\section{Randomization}

Randomization was performed by one of the researchers who did not participate in recruitment, data collection or assessment. This researcher, therefore, did not have direct contact with the other members of the research team. After the screening assessment, block randomization was performed using opaque envelopes.

\section{Blinding}

Blinding of trial participants and the intervention facilitator was not possible. All outcomes were assessed by a researcher blinded to group allocation. Participants were asked not to disclose their allocation to the physical therapist who undertook the assessments.

\section{Data collection}

Participants were interviewed about their sociodemographic characteristics (age, gender, height, weight), health (number of chronic diseases, and number of medications currently in use, physical activity level (through the International Physical Activity Questionnaire), frequency of weekly physical activity and depressive symptoms (through GDS-15).

\section{Statistical analyses}

Descriptive statistics were presented for all variables. From the baseline, final and follow-up data, ShapiroWilk tests were carried out to verify the hypothesis of normal distribution. In order to analyse possible effects of assessment, group and interactions between assessments and group, a Repeated Measures ANOVA (RM-ANOVA) was used. The Bonferroni post hoc test was used if a significant effect was found in the RMANOVA. A significance level of $5 \%(p<0.05)$ was adopted and generalized effect sizes were calculated for all analyses. All analyses were performed using the Jeffreys's Amazing Statistics Program (JASP) 0.9.2 computer software. 


\section{Results}

Participant characteristics at baseline

Demographic and clinical characteristics at baseline of the participants in the two groups are presented in Table 3. There were no significant differences between the two groups. Fourteen individuals (five men and nine women), participated in the study, eight in the IVG and six in the PEP. The mean age of participants was 69.37 (6.39) years in the IVG and 68.33 (5.88) of years in the PEP. According to the IPAQ, the participants in the IVG were classified as: $25 \%$ sedentary, $62.5 \%$ active, and $12.5 \%$ super active and the participants in the PEP as: $16.7 \%$ sedentary, $66.7 \%$ active, and $16.7 \%$ super active without differences between the two groups.

Table 3 - Demographic and clinical characteristics at baseline

\begin{tabular}{lccc}
\hline Variables & \multicolumn{2}{c}{ Group } & p-value \\
\cline { 2 - 3 } & $\begin{array}{c}\text { IVG } \\
(\mathbf{N}=8)\end{array}$ & $\begin{array}{c}\text { PEP } \\
(\mathbf{N}=6)\end{array}$ & \\
\hline Aged (years) & & & 0.761 \\
Mean (SD) & $69.4(6.4)$ & $68.3(5.9)$ & \\
Body Mass Index \\
(kg/m²)
\end{tabular}

\section{Outcome}

There were significant effects of assessment (RMANOVA, $\mathrm{p}=0.001$ ) and group (RM-ANOVA, $\mathrm{p}=0.020$; Cohen's $d=-0.701)$, without interaction between factors (RM-ANOVA, $\mathrm{p}=0.980$ ), in the GDS-15 (Table
4). Both groups showed improvement in the GDS-15 post intervention assessment (Bonferroni post hoc test, $p=0.01$; Cohen's $d=1.393)$, that was maintained in the follow up assessment (Bonferroni post hoc test, $\mathrm{p}=0.002$; 
Cohen's $d=1.068$ ). Table 5 shows the Bonferroni post hoc test comparisons. There was no significant difference between groups at the pretreatment assessment, showing that the groups are comparable.

Table 4 - Intergroups comparison

\begin{tabular}{|c|c|c|c|c|c|c|c|c|}
\hline & $\begin{array}{c}\text { Pretreatment } \\
\text { assessment } \\
\text { Mean(SD) }\end{array}$ & $\begin{array}{c}\text { Post } \\
\text { treatment } \\
\text { assessment } \\
\text { Mean (SD) }\end{array}$ & $\begin{array}{l}\text { Follow-up } \\
\text { assessment } \\
\text { Mean (SD) }\end{array}$ & $\begin{array}{l}\text { Mean Difference } \\
\text { (SD) } \\
\text { Post-intervention - } \\
\text { Baseline Mean (SD) }\end{array}$ & $\begin{array}{l}\text { Mean Difference } \\
\qquad \text { (SD) } \\
\text { Follow - Baseline } \\
\text { Mean (SD) }\end{array}$ & $\begin{array}{l}\text { Group } \\
\text { (p) }\end{array}$ & $\begin{array}{c}\text { Assessment } \\
\text { (p) }\end{array}$ & $\begin{array}{c}\text { Assessment } \\
x \text { Group (p }\end{array}$ \\
\hline \multicolumn{9}{|c|}{ GDS-15 } \\
\hline \multicolumn{9}{|c|}{$\begin{array}{l}\text { (RM- } \\
\text { ANOVA) }\end{array}$} \\
\hline IVG & $4.9(2.1)$ & $2.4(1.5)$ & $2.9(1.6)$ & $-2.500^{\mathrm{a} \#}$ & $-2.000^{c^{\wedge}}$ & & & \\
\hline PEP & $7.3(3.1)$ & $4.8(2.3)$ & $5.5(1.6)$ & $-2.500 b *$ & $-1.833^{\circ}$ & 0.022 & $<0.001$ & 0.980 \\
\hline
\end{tabular}

Note: RM ANOVA (Repeated Measures Variance Analysis), a. Bonferroni Post Hoc Test $(p=0.007)$, b. Bonferroni Post Hoc Test $(p=0.023)$, c. Bonferroni Post Hoc Test $(p=0.041)$; \#.Cohen's d $(-1.064),{ }^{*}$.Cohen's d $(-0.921),{ }^{\wedge}$. Cohen's d $(-0.851),{ }^{\circ}$. Cohen's d $(-0.675)$.

Table 5 - Post Hoc Comparisons - Group Assessment

\begin{tabular}{|c|c|c|c|c|c|c|}
\hline & & $\begin{array}{c}\text { Mean Dif- } \\
\text { ference }\end{array}$ & SE & $t$ & $\mathbf{p}$ & bonf \\
\hline \multirow[t]{5}{*}{ IVG, Pre.treatment } & PEP, Pre.treatment & -2.458 & $\begin{array}{r}1.10 \\
7\end{array}$ & $\begin{array}{r}2.22 \\
0\end{array}$ & $\begin{array}{r}0.56 \\
9\end{array}$ & \\
\hline & IVG, Post.treatment & 2.500 & $\begin{array}{r}0.62 \\
8\end{array}$ & $\begin{array}{r}3.97 \\
9\end{array}$ & $\begin{array}{r}0.00 \\
8\end{array}$ & * \\
\hline & PEP, Post.treatment & 0.042 & $\begin{array}{r}1.10 \\
7\end{array}$ & $\begin{array}{r}0.03 \\
8\end{array}$ & $\begin{array}{r}1.00 \\
0\end{array}$ & \\
\hline & IVG, Follow.up & 2.000 & $\begin{array}{r}0.62 \\
8\end{array}$ & $\begin{array}{r}3.18 \\
4\end{array}$ & $\begin{array}{r}0.06 \\
0\end{array}$ & \\
\hline & PEP, Follow.up & -0.625 & $\begin{array}{r}1.10 \\
7\end{array}$ & $\begin{array}{r}0.56 \\
5\end{array}$ & $\begin{array}{r}1.00 \\
0\end{array}$ & \\
\hline \multirow[t]{4}{*}{ PEP, Pre.treatment } & IVG, Post.treatment & 4.958 & $\begin{array}{r}1.10 \\
7\end{array}$ & $\begin{array}{r}4.47 \\
9\end{array}$ & $\begin{array}{r}0.00 \\
3\end{array}$ & $\begin{array}{l}\star \\
\star\end{array}$ \\
\hline & PEP, Post.treatment & 2.500 & $\begin{array}{r}0.72 \\
5\end{array}$ & $\begin{array}{r}3.44 \\
6\end{array}$ & $\begin{array}{r}0.03 \\
2\end{array}$ & * \\
\hline & IVG, Follow.up & 4.458 & $\begin{array}{r}1.10 \\
7\end{array}$ & $\begin{array}{r}4.02 \\
7\end{array}$ & $\begin{array}{r}0.01 \\
0\end{array}$ & * \\
\hline & PEP, Follow.up & 1.833 & $\begin{array}{r}0.72 \\
5\end{array}$ & $\begin{array}{r}2.52 \\
7\end{array}$ & $\begin{array}{r}0.27 \\
7\end{array}$ & \\
\hline \multirow[t]{2}{*}{ IVG, Post.treatment } & PEP, Post.treatment & 2.458 & 1.107 & $\begin{array}{r}2.22 \\
0\end{array}$ & $\begin{array}{r}0.56 \\
9\end{array}$ & \\
\hline & IVG, Follow.up & -0.500 & 0.628 & $\begin{array}{r}0.79 \\
6\end{array}$ & $\begin{array}{r}1.00 \\
0\end{array}$ & \\
\hline \multirow[t]{3}{*}{ PEP, Post.treatment } & PEP, Follow.up & -3.125 & 1.107 & $\begin{array}{r}2.82 \\
3\end{array}$ & $\begin{array}{r}0.15 \\
7\end{array}$ & \\
\hline & IVG, Follow.up & 1.958 & 1.107 & $\begin{array}{r}1.76 \\
9\end{array}$ & $\begin{array}{r}1.00 \\
0\end{array}$ & \\
\hline & PEP, Follow.up & -0.667 & 0.725 & $\begin{array}{r}0.91 \\
9\end{array}$ & $\begin{array}{r}1.00 \\
0\end{array}$ & \\
\hline IVG, Follow.up & PEP, Follow.up & -2.625 & 1.107 & $\begin{array}{r}2.37 \\
1 \\
\end{array}$ & $\begin{array}{r}0.41 \\
7\end{array}$ & \\
\hline
\end{tabular}

Note: P-value adjusted for comparing a family of 15 ; bonf, Bonferroni post hoc test; SE, Standard Error. ${ }^{\star} p<.05,{ }^{\star \star} p<.01$ 


\section{Discussion}

The objective of this study was to compare the effect of virtual reality through commercial IVG in relation to physical exercise on the depressive symptoms of older adults. Our clinical hypothesis was that the VR intervention based on the Interactive Video Game Kinect Adventures would be superior to physical exercise according to the reasons: the games offer higher visual and auditory feedback, the score system related to the performance can increase the engagement and motivation of the participants and the cognitive demands [19]. However, the results showed that both intervention protocols promoted a reduction in depressive symptoms, without superiority of the interactive video game.

The literature includes several studies that report the positive effects of physical exercises on mental disorders [22, 23]. Anderson and Shivakumar stated that physical exercise is related to the reduction of symptoms of anxiety and depression. This statement directly corroborates with the results of this study that showed that both exercise interventions were effective in reducing depressive symptoms in the elderly [22]. Chan et al. stated that physical exercises with light or moderate intensities are effective for depression in the elderly [23]. Physical exercises in general can stimulate many physiological changes which result in an improvement in mood state and self-esteem, and lower stress and anxiety levels. The suggested mechanism for this is the increase in endorphin levels [24], body temperature, mitochondrial function, and mitochondriogenesis [25], and the increase in the mammalian target of rapamycin (mTor) signaling, neurotransmitter production, and attenuation of the hypothalamic pituitary-adrenal axis response to stress [26].

Huang et al. [27] compared the effectiveness of a physical fitness exercise program and a cognitive behavior therapy program on depressive symptoms. Fifty-seven community dwelling older adults were randomly assigned to one of three groups: physical fitness exercise program group (PFG), cognitive behavior therapy (CBT) group, and control group. The PFG performed training three-times/week (12-week), composed of a warm-up, cardiovascular exercises, muscle strength exercises, and a cool-down. The CBT intervention consisted of 12 weekly sessions and the main strategy was to restructure misconceptions to promote positive thinking and behavior. The control group received no extra care. The results showed that the CBT demonstrated significantly lower symptoms of depression immediately after the intervention and the PFG demonstrated decreased GDS-15 scores at three time-point comparisons (immediately, three, and six months after the intervention). These results corroborate indirectly and secondarily with the present study, as they show that the group that performed the physical exercise protocol also showed improvement in relation to depressive symptoms. Thus, we suggest that protocols that are composed of physical exercises can stand out in relation to mood gains in patients with depression. On the other hand, studies have shown that virtual reality exercises benefit older adults with depression. A recent systematic review and metaanalysis [28] suggested that although the games were designed for young generations, an increasing percentage of older adults are engaging in playing them. A possible explanation is that older adults develop depression mainly because of physical illness or social isolation [29]. Since exergames can promote both physical well-being and social interaction, they may contribute to reducing depressive symptoms in the older population [28]. Bacha etal. [19] add that one advantage of video games is that they are designed to be fun and motivating and these characteristics are essential to motivate older adults to continue playing the games. In addition, some motor demands recruited by the games (such as jumping, crouching, fast displacement, upper limb movements) can help older adults to achieve the recommendations of the American College of Sports Medicine, which stresses the need for aerobic activities, aerobic fitness, activities that maintain or increase flexibility, and balance exercises [30].

King et al. [31] proposed the psychological taxonomy of characteristics of videogames, namely: (1) the player's ability to manipulate and control how the video game functions and consecutive games, as well as the ability to save progress to correct errors, manage various dynamic resources, and display critical emotional stimuli such as frustration, sadness, and fear which can be trained and released, which are essential for emotional control; (2) narrative and identity features that refer to the role of narrative as a means of immersing the player in the video game and the ways in which the player can take on another identity in the game. The personalization features performed through the desire of the players can influence the self-perception of individuals; and (3) feedback features in which players are rewarded 
through items such as scores and prizes that favor an overall assessment of their skills, favoring self-testing. In addition, given the enjoyable nature of currentlyavailable VR exercise games and the positive effects that exercise has on anxiety and depression, VR exercise might be viewed as a potentially effective approach to alleviate anxiety- and depression-related symptomatology [32].

As explained, physical exercise, whether conventional or performed through interactive games, is beneficial for improving depressive symptoms in older adults. This was the first pilot study to compare the effects of using virtual reality through commercial Interactive Video Game Kinect Adventures ("Space Pop," “20,000 Leaks," “Reflex Ridge," and “River Rush”.) with physical exercises intervention in the depressive symptoms of older adults. However, the low number of study participants may have influenced the research results. Thus, further clinical trials are needed to prove the initial study hypothesis.

\section{Conclusion}

The results of this study suggest that both Interactive Video Game Kinect Adventures games and physical exercise provide positive effects on the mood of older adults. Further studies are needed to investigate whether interactive video games promote greater effects than conventional exercises.

\section{References}

1. Bird MJ, Parslow RA. Potential for community programs to prevent depression in older people. Med J Aust. 2002;177(S7):S107-10.

2. Duarte MB, Rego MAV. Comorbidade entre depressão e doenças clínicas em um ambulatório de geriatria. Cad Saude Publica. 2007;23(3):691-700.

3. Matias AGC, Fonsêca MA, Gomes MLF, Matos MAA. Indicators of depression in elderly and different screening methods. Einstein (Sao Paulo). 2016;14(1):6-11.

4. Sadock BJ, Sadock VA. Compêndio de Psiquiatria: Ciência do Comportamento e Psiquiatria Clínica. Porto Alegre: Artmed; 2007.
5. Frazer CJ, Christensen H, Griffiths KM. Effectiveness of treatments for depression in older people. Med J Aust. 2005;182(12):627-32.

6. Bridle C, Spanjers K, Patel S, Atherton NM, Lamb SE. Effect of exercise on depression severity in older people: Systematic review and meta-analysis of randomised controlled trials. Br J Psychiatry. 2012;201(3):180-5.

7. Blumenthal JA, Babyak MA, Moore KA, Craighead WE, Herman S, Khatri P, et al. Effects of exercise training on older patients with major depression. Arch Intern Med. 1999;159(19):2349-56.

8. Penninx BWJH, Rejeski WJ, Pandya J, Miller ME, Di Bari M, Applegate WB, et al. Exercise and depressive symptoms: A comparison of aerobic and resistance exercise effects on emotional and physical function in older persons with high and low depressive symptomatology. J Gerontol B Psychol Sci Soc Sci. 2002;57(2):P124-32.

9. Mikkelsen K, Stojanovska L, Polenakovic M, Bosevski M, Apostolopoulos V. Exercise and mental health. Maturitas. 2017;106:48-56.

10. Peluso MAM, Andrade LHSG. Physical activity and mental health: the association between exercise and mood. Clinics. 2005;60(1):61-70.

11. Sharma A, Madaan V, Petty FD. Exercise for mental health. Prim Care Companion J Clin Psychiatry. 2006;8(2):106.

12. Păsărelu CR, Andersson G, Nordgren LB, Dobrean A. Internet-delivered transdiagnostic and tailored cognitive behavioral therapy for anxiety and depression: a systematic review and meta-analysis of randomized controlled trials. Cogn Behav Ther. 2017;46(1):1-28.

13. Wiederhold BK, Bouchard S. Advances in Virtual Reality and Anxiety Disorders. Boston, MA: Springer; 2014. $287 \mathrm{p}$.

14. McEwen D, Taillon-Hobson A, Bilodeau M, Sveistrup H, Finestone H. Virtual reality exercise improves mobility after stroke: An inpatient randomized controlled trial. Stroke. 2014;45(6):1853-5.

15. Morina N, Ijntema H, Meyerbröker K, Emmelkamp PMG. Can virtual reality exposure therapy gains be generalized to real-life? A meta-analysis of studies applying behavioral assessments. Behav Res Ther. 2015;74:18-24. 
16. Didehbani N, Allen T, Kandalaft M, Krawczyk D, Chapman S. Virtual Reality Social Cognition Training for children with high functioning autism. Comput Human Behav. 2016;62:703-11.

17. Gutiérrez-Maldonado J, Wiederhold BK, Riva G. Future directions: How virtual reality can further improve the assessment and treatment of eating disorders and obesity. Cyberpsychol Behav Soc Netw. 2016;19(2):148-53.

18. Villani D, Carissoli C, Triberti S, Marchetti A, Gilli G, Riva G. Videogames for Emotion Regulation: A Systematic Review. Games Health J. 2018;7(2):85-99.

19. Bacha JMR, Gomes GCV, Freitas TB, Viveiro LAP, Silva KG, Bueno GC, et al. Effects of Kinect Adventures games versus conventional physical therapy on postural control in elderly people: A randomized controlled trial. Games Health J. 2018;7(1):24-36.

20. IPAQ Scoring Protocol. Guidelines for the data processing and analysis of the International Physical Activity Questionnaire. 2005 [cited 2020 Apr 25]. Available from: https://tinyurl.com/ybgfsx8j.

21. Marty MA, Pepin R, June A, Segal DL. Geriatric Depression Scale. In: Abou-Saleh MT, Katona C, Kumar A (Eds.). Principles and Practice of Geriatric Psychiatry. 3rd ed. Hoboken, NJ: Wiley-Blackwell; 2010. p. 152-6.

22. Anderson E, Shivakumar G. Effects of exercise and physical activity on anxiety. Front Psychiatry. 2013;4:27.

23. Chang YC, Lu MC, Hu IH, Wu WCI, Hu SC. Effects of different amounts of exercise on preventing depressive symptoms in community-dwelling older adults: a prospective cohort study in Taiwan. BMJ Open. 2017;7(4):e014256.
24. Fuss J, Steinle J, Bindila L, Auer MK, Kirchherr H, Lutz B, et al. A runner's high depends on cannabinoid receptors in mice. Proc Natl Acad Sci USA. 2015;112(42):13105-8.

25. Aguiar Jr AS, Stragier E, Scheffer DL, Remor AP, Oliveira PA, Prediger RD, etal. Effects of exercise on mitochondrial function, neuroplasticity and anxio-depressive behavior of mice. Neuroscience. 2014;271:56-63.

26. Watson K, Baar K. mTOR and the health benefits of exercise. Semin Cell Dev Biol. 2014;36:130-9.

27. Huang TT, Liu CB, Tsai YH, Chin YF, Wong CH. Physical fitness exercise versus cognitive behavior therapy on reducing the depressive symptoms among communitydwelling elderly adults: A randomized controlled trial. Int J Nurs Stud. 2015;52(10):1542-52.

28. Li J, Theng YL, Foo S. Effect of Exergames on Depression: A Systematic Review and Meta-Analysis. Cyberpsychol Behav Soc Netw. 2016;19(1):34-42.

29. Cole MG, Dendukuri N. Risk factors for depression among elderly community subjects: A systematic review and meta-analysis. Am J Psychiatry. 2003;160(6):1147-56.

30. Nelson ME, Rejeski WJ, Blair SN, Duncan PW, Judge JO, King AC, et al. Physical activity and public health in older adults: recommendation from the American College of Sports Medicine and the American Heart Association. Circulation. 2007;116(9):1094-105.

31. King D, Delfabbro P, Griffiths M. Video game structural characteristics: a new psychological taxonomy. Int J Ment Health Addiction. 2010;8(1):90-106.

32. Bartsch A, Vorderer P, Mangold R, Viehoff R. Appraisal of emotions in media use: toward a process model of meta-emotion and emotion regulation. Media Psychol. 2008;11(1):7-27.

Received: 06/23/2020

Recebido: 23/06/2020

Approved: 09/30/2020

Aprovado: 30/09/2020 
In the article "Kinect Adventures versus Physical Exercise on depressive symptoms of older adults: A pilot study", DOI number: http://dx.doi.org/10.1590/1980-5918.033.A071, published in Revista Fisioterapia em Movimento, v.33, e003372, 2020, (http://www.scielo.br/scielo.php?script=sci_arttext\&pid=S010351502020000100268\&tlng=en), on page 1 :

\section{Where it reads:}

Jéssica Maria Ribeiro Bacha ${ }^{[a]}$, Gisele Cristine Vieira Gomes ${ }^{[a]}$, Tatiana Beline de Freitas ${ }^{[a]}$, Camila Torriani$\operatorname{Pasin}^{[a, b]}$, Belinda Lange ${ }^{[a]}$, José Eduardo Pompeu ${ }^{[a] *}$

\section{It should read:}

Jéssica Maria Ribeiro Bacha ${ }^{[a]}$, Gisele Cristine Vieira Gomes ${ }^{[a]}$, Tatiana Beline de Freitas ${ }^{[a]}$, Camila TorrianiPasin ${ }^{[a]}$, Belinda Lange ${ }^{[b]}$, José Eduardo Pompeu ${ }^{[a] *}$ 